\title{
Building Brand Commitment Through Brand Passion
}

\author{
NGUYẼ̃N TH! MAI TRANG \\ University of Economics and Law under Vietnam National University - HCMC \\ Email: mai.ntmt2001@gmail.com
}

\begin{abstract}
ARTICLE INFO
ABSTRACT

Received:

This study examines the effect of brand commitment on brand

Jan. 15, 2013 passion. It also investigates the role of some selected promotion-mix elements (i.e., advertising and public relations) in brand passion. A Received in revised form March 24, 2013 Accepted: model depicting these relationships was tested with a sample of 386 consumers in HCMC, Vietnam. The results show that attitudes toward advertising and public relations have positive impacts on brand passion, and subsequently brand passion is a key factor influencing brand commitment. These findings imply that a firm is able to enhance

Keywords: brand passion brand commitment brand passion through advertising and public relations. In so doing, the firm will enjoy the benefit created by committed consumers of its brands.
\end{abstract} public relations advertising 


\section{INTRODUCTION}

Brands and branding have attracted the attention of both academics and practitioners around the world (see, for example, Aaker, 1991; Aaker et al., 2004; Keller, 1993; Woodside and Walser, 2007; Yorkston et al., 2010). Firms are urged to build deep affection for their brands and they believe that deep emotional brand connections (e.g., brand passion) can bring high profits for firms (Yim et al., 2008). Recently, a survey conducted by B\&Company Vietnam and Nikkei BP Consultancy indicates that Nokia, Honda, and Vinamilk received their highest ranking in terms of affection, connectedness, and bondedness. Consumers are also disappointed when, for any reasons, they are unable to see their passionate brands in the market. For example, many consumers think that they would feel very sad when Google, Nokia, and Vinamilk disappeared in the market.

Several studies have focused on how to build strong brands, such as building brand equity (Keller, 1993), establishing brand loyalty (Yim et al., 2008), investing in consumer-brand relationships (De Wulf et al., 2001). Among the concepts used to explain a strong brand, brand passion has been studied by academics for several years (see, for example, Fournier, 1998; Yim et al., 2008; Veloutsou \& Moutinho, 2009; Batra et al., 2012). Gallup Inc. defines brand passion as the belief that the brand fits well to the consumer's need and is irreplaceable. Brand passion reflects strong affection for a specific brand. Unfortunately, some research on brand passion and brand commitment have focused heavily on advanced economies. Little research has been devoted to investigating these concepts in developing economies, especially, in transition markets like Vietnam. In addition, as marketing is moving from the marketing mix paradigm to the relationship marketing paradigm (Gronroos, 1994), there is a need for examining the role of traditional marketing-mix elements in building brand passion and brand commitment.

An understanding of key antecedents of brand passion as well as the relationship between brand passion and brand commitment is of interest for practitioners and academics. For that reason, this study investigates the role of brand passion in brand commitment in a transitional market, i.e. Vietnam. It also investigates the role of some selected promotion-mix elements (i.e. advertising and public relations) in brand passion. Two selected tools in the promotional mix are chosen because advertising and public relations still play key roles in building strong brands in Vietnam. The rest of the paper 
is organized around four key points: conceptual model, method, results, and discussions and conclusions.

\section{LITERATURE REVIEW AND HYPOTHESES}

\section{- Conceptual model:}

This study proposes a conceptual model depicted in Figure 1. The model hypothesizes that attitudes toward advertising and public relations are antecedents of brand passion. Further, brand passion has a positive impact on brand commitment.

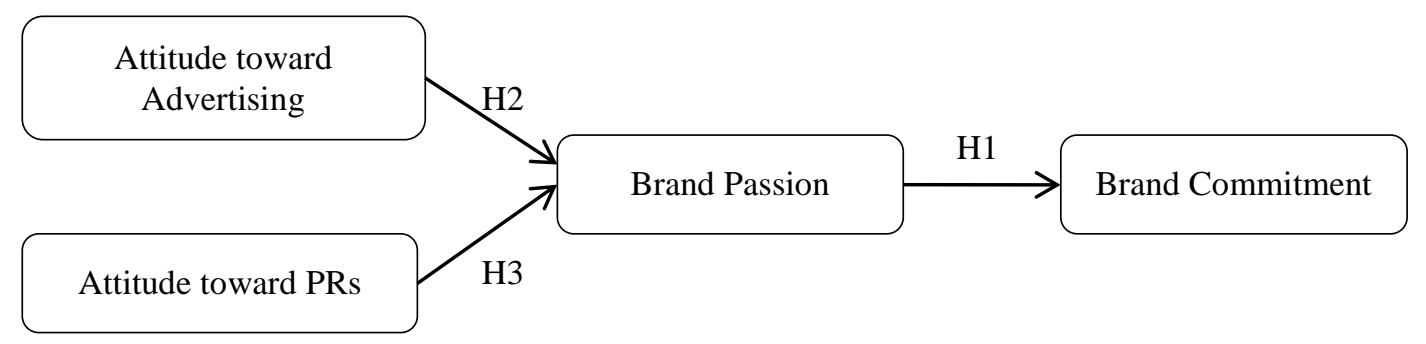

Figure 1: Conceptual Model

\section{- Brand commitment:}

Brand commitment is considered as a focal construct in relationship marketing and is popular mainly in business-to-business marketing (Morgan \& Hunt, 1994). Past research in business-to-business marketing contexts suggests that the commitment construct was conceptualized as an enduring desire to maintain a valued relationship (Morgan \& Hunt, 1994). The literature on consumer behavior suggests that brand commitment refers to the way consumers develop a long-term relationship with a brand, including an emotional attachment to the brand within a product class (Chaudhuri \& Holbrook, 2002) and a desire to maintain the relationship. In other words, commitment to a relationship denotes a voluntary continuance in the relationship. Sung \& Choi (2010) also suggest that consumers who are committed to a brand might not have a greater propensity to switch to competitive brands.

\section{- Brand passion:}

Consumers with strong affection for a brand will feel that something is missing if the brand is not used (Fournier, 1998; Smit et al., 2007). Therefore, brand passion entails something that consumers could not help possessing. To create passionate consumers is to acquire a valuable asset for every brand. In so doing, a brander should become a passion brander. He or she should center on the relationship between the brand and its 
consumers around a consumer passion, and the leverage of that passion in order to create value for all in the relationship. Brand passion reflects strong affection for a specific brand. Therefore,

H1: There is a positive relationship between brand passion and brand commitment.

\section{- Attitudes toward advertising:}

The attitude of consumers toward advertising, which can be defined as "a learned predisposition to respond in a consistently favorable manner toward advertising in general" (MacKenzie \& Lutz, 1989, pp. 53-54), has received considerable attention from researchers and practitioners (Heath \& Gaeth, 1994; Mehta, 2000). Advertising is believed to be an effective tool for promoting a brand, especially to build consumers' trust in the brand ( $\mathrm{Li} \&$ Miniard, 2006). Positive attitudes of consumers toward advertising programs of a brand will stimulate consumers to recognize the characteristics of the brand and to compare it with competing brands. In addition, when consumers prefer the brand's advertising programs, they intend to search for more information about the brand. This improves consumers' attitudes, perceptions and knowledge about the brand (Kirmani \& Zeithaml, 1993; MacKenzie \& Lutz, 1989; Mehta, 2000). These will influence consumers' evaluation of and trust in the brand (Li \& Miniard, 2006; Smit et al., 2007). Thus,

$\mathrm{H} 2$ : There is a positive relationship between attitudes toward advertising and brand passion.

\section{- Attitudes toward public relations}

Together with advertising, public relations play a pivotal role in building brand images. It can be defined as a marketing function that focuses on long-term patterns of interaction between an organization or its brands and publics, with the aim of establishing their mutual understanding, goodwill and support, and hence enhancing their relationships (Smith, 2005). When consumers have a favorable attitude toward PR programs of a brand, they form a positive attitude toward the brand. Compared to advertising, public relations are more authentic and credible to consumers (e.g., Kotler, 2003). Thus,

H3: There is a positive relationship between attitudes toward public relations and brand passion. 


\section{METHOD}

- Procedure and sample:

Survey data were used to test the conceptual model. The survey was undertaken using face-to-face interviews with 386 consumers in HCMC, Vietnam. Confirmatory factor analysis (CFA) was used to test the measurement models, and structural equation modeling (SEM) to test the conceptual model and hypotheses.

The sample included $200(51.8 \%)$ female consumers and 185 (48.2\%) male consumers. In terms of age, there were 240 (62.2\%) consumers who were less than 30 years of age, and $144(37.8 \%)$ consumers who were 30 years of age or older. In terms of income, $251(65 \%)$ consumers had a monthly income lower than or equal to VND5 million, and 151 (35\%) consumers had a monthly income higher than VND5 million.

- Measurement:

Brand passion and brand commitment were measured by three items each. These items were based on Aaker et al. (2004) and Smit et al. (2007). The items that tap into brand passion are: (1) I feel very lovely when talking about X, (2) I feel great affectionate for $X$, (3) I feel very peaceful when mentioning $X$. The items that tap into brand commitment are: (1) I always stick with X, (2) To me, $X$ is an irreplaceable brand, (3) I am very loyal to $X$. Attitudes toward advertising were measured by two items: (1) the advertising programs of $X$ are very attractive, and (2) I like the advertising programs of $\mathrm{X}$. Finally, attitudes toward public relations were measured by two items (e.g. the public relations programs of $\mathrm{X}$ are very valuable for society; I rate highly the public relations programs of X). All items were measured by a seven-point Likert scale, anchored by 1 : strongly disagree and 7: strongly agree.

\section{DATA ANALYSIS AND RESULTS}

- Measurement validation:

The data exhibited slight deviations from normal distribution, however, all univariate kurtoses and skewnesses were within the range of $[-1,1]$. Therefore, the maximum likelihood estimation method was used (Muthen \& Kaplan, 1985). There were four constructs under investigation: attitudes toward advertising, attitudes toward public relations, brand passion, and brand commitment. These constructs were all first-order ones. 
The final measurement model had 29 degrees of freedom. The CFA results indicated that this model received an acceptable fit to the data: $\chi^{2}[29]=87.84(\mathrm{p}=.000)$; GFI $=$ $.965 ; \mathrm{CFI}=.982$; and, RMSEA $=.065$. All factor loadings were substantial $(\geq .69)$ and significant $(\mathrm{p}<.001)$. All factor correlations were significantly below unity $(\mathrm{p}<.001)$. These findings supported convergent and discriminant validity between the constructs (Steenkamp \& van Trijp, 1991). Further, all measures satisfied the requirement for composite reliability $\left(\rho_{c} \geq 0.72\right.$; Steenkamp \& van Trijp, 1991) and variance extracted $\left(\rho_{\mathrm{vc}} \geq 0.67\right.$; Fornell \& Larcker, 1981). In sum, the validation shows that all the measures used in this study satisfied the requirements for construct reliability and validity. Consequently, they were used to test the structural model and hypotheses.

- Structural results: Hypothesis testing

SEM was used to test the hypotheses. The structural model had 31 degrees of freedom. The SEM results indicated that the model received an acceptable fit: $\chi^{2}[31]=$ $105.72(\mathrm{p}=.000)$; GFI $=.958 ; \mathrm{CFI}=.977$; and, RMSEA $=.071$. It is noted that no improper solutions were found in any results of the tests: Heywood cases were absent; all error-term variances were significant; and, all standardized residuals were less than |2.58|.

Consistent with $\mathrm{H} 1$, a positive relationship between brand passion and brand commitment was found $(\beta=0.73 ; \mathrm{p}<.001$; Table 1$)$. This hypothesis was supported. $\mathrm{H} 2$ posits a positive relationship between advertising and brand passion. This hypothesis was supported $(\beta=0.33 ; \mathrm{p}<.001$; Table 1$)$. Finally, H3 proposes a positive relationship between public relations and brand passion. This hypothesis was supported $(\beta=0.21 ; \mathrm{p}$ $<.001$; Table 1).

Table 1: Structural Results

\begin{tabular}{clccccc}
\hline Hypothesis & \multicolumn{1}{c}{ Structural path } & B & SE & $\boldsymbol{\beta}$ & CR & p-value \\
\hline H1 & Brand passion $\rightarrow$ Brand commitment & 0.29 & 0.047 & 0.33 & 6.10 & 0.000 \\
H2 & Advertising $\rightarrow$ Brand passion & 0.17 & 0.044 & 0.21 & 3.88 & 0.000 \\
H3 & Public relations $\rightarrow$ Brand passion & 0.69 & 0.042 & 0.73 & 12.88 & 0.000 \\
\hline
\end{tabular}

Note: B: unstandardized estimate; $\boldsymbol{\beta}$ : standardized estimate; SE: standard error; CR: critical ratio 


\section{CONCLUSIONS}

This work contributes to an under-investigated area of marketing in the transition economy of Vietnam by investigating the role of attitudes toward advertising and public relations in brand passion, and subsequently brand commitment. The empirical findings support the conceptualization of brand passion conceived by researchers in advanced economies (Batra et al. 2012). In addition, the findings show that advertising and public relations still play important roles in building passionate brands. Such findings are expected to enrich the literature on brand-consumer relationships in transition economies, and can serve as an initiation for further research in relationship marketing in such economies.

The results of this study suggest firms should use advertising and public relations tools to build brand passion and brand commitment. Therefore, Vietnamese firms wanting to achieve passionate and committed consumers should pay attention to their advertising and public relations programs. Programs that raise favorable attitudes of consumers will result in a high level of brand passion, leading to a high level of brand commitment.

This study has several shortcomings. First, it investigated only two elements of the promotion mix. Other marketing-mix elements may have an effect on brand passion. Also, several other factors can be antecedents of brand passion and brand commitment such as brand personality impressions (e.g. Aaker, 1997; Johar et al., 2005), and customer values (e.g. Durgee, 1996; Heaven, 1993). These factors should be investigated in future research. In addition, although the data were collected in HCMC, a major business center of Vietnam, the geographic coverage was limited and the sampling procedure was non-probabilistic. Consequently, the interpretation of the results should be undertaken with cautions. Future research should use a more representative sample size

\section{References}

Aaker, D. A. (1991), Managing Brand Equity, New York: The Free Press.

Aaker, J., S. Fournier \& S.A. Brasel (2004), "When Good Brands Do Bad", Journal of Consumer Research, 31 (June), 1-16.

Batra, R., A. Ahuvia \& R.P. Bagozzi (2012), "Brand Love”, Journal of Marketing, 76 (March), 1-16. 
Chaudhuri, A. \& M. B. Holbrook (2002), "Product-Class Effects on Brand Commitment and Brand Outcomes: The Role of Brand Trust and Brand Effect", Journal of Brand Management, 10: 3358.

De Wulf, K., G. Odekerken-Schoroder \& D. Iacobucci (2001), "Investments in Consumer Relationships: A Cross-country and Cross-industry Exploration”, Journal of Marketing, 65(4), 33-50.

Đình Hải (2011), “Thành công của Vinamilk: Giá trị của chiến lược đúng” at http://vtc.vn/488276649/dinh-duong-va-suc-khoe/thanh-cong-cua-vinamilk-gia-tri-cua-chien-luoc-dung.htm retrieved on Aug. 29, 2012.

Duffy, N. (2003), Passion Branding: Harnessing the Power of Emotion to Build Strong Brands, John Wiley and Son, Chichester.

Durgee, J. F. (1996), “Translating Values in Product Wants”, Journal of Advertising Research, 36(6), 90-100.

Fournier, S. (1998), “Consumers and Their Brands: Developing Relationship Theory in Consumer Research", Journal of Consumer Research, 24 (March), 343-373.

Johar, G. V., J. Sengupta \& J.L. Aaker (2005), "Two Roads to Updating Brand Personality Impressions: Trait Versus Evaluative Inferencing", Journal of Marketing Research, 42(November), 458-469.

Keller, K.L. (1993), Conceptualizing, Measuring, and Managing Customer-Based Brand Equity”, Journal of Marketing, 57(1): 1-22.

Kirmani, A. \& V. Zeithaml (1992), “Advertising Strategy for Creating Brand Image” in D.A. Aaker \& A. Biel (Eds.), Brand Equity and Advertising: Advertising's Role in Building Strong Brands (pp. 143-162), Hillsdale, NJ: Erlbaum.

Kotler, P. (2003), Marketing Management, $11^{\text {th }}$ ed., Upper Saddle River, NJ: Prentice-Hall.

Li, F., \& P. W. Miniard (2006), "On the Potential for Advertising to Facilitate Trust in the Advertised Brand”, Journal of Advertising, 35(4), 101-112.

MacKenzie, S. B. \& R. J. Lutz (1989), An Empirical Examination of the Structural Antecedents of Attitude Toward the Ad in an Advertising Pretesting Context”, Journal of Marketing, 53(April), 48-65.

McEwen, W.J. (2004), “Getting Emotional about Brands”, Gallup Management Journal, September 09, 1-4.

Mehta, A. (2000), “Advertising Attitudes and Advertising Effectiveness", Journal of Advertising Research, 40(3), 67-72.

Morgan, R. M. \& S. D. Hunt (1994), "The Commitment-Trust Theory of Relationship Marketing", Journal of Marketing, 58(3): 20-38. 
Muthen, B. \& D. Kaplan (1985), “A Comparison of Some Methodologies for the Factor Analysis of Non-Normal Likert Variables”, British Journal of Mathematical and Statistical Psychology, 38(May), 171-180.

Nguyen, T.D., N.J. Barrett \& K.E. Miller (2004), Brand Passion and Its Antecedents: An Empirical Study of International Brands in Vietnam, EMAC 2004 Proceedings, Murcia, Spain.

Smit, E., F. Bronner \& M. Tolboom (2007), "Brand Relationship Quality and Its Value for Personal Contact”, Journal of Business Research . vol. 60, pp 627-633.

Smith, R.D. (2005), Strategic Planning for Public Relations, Mahwah, NJ: Lawrence Erlbaum Associates.

Steenkamp, J.B.E.M. \& H.C.M. van Trijp (1991), “The Use of LISREL in Validating Marketing Constructs", International Journal of Research in Marketing, 8(4), 283-299.

Sung, Y. \& S.M. Choi (2010), “I Won’t Leave You Although You Disappoint Me: The Interplay Between Satisfaction, Investment, and Alternatives in Determining Consumer-Brand Relationship Commitment", Psychology \& Marketing, 27(11): 1050-1074.

Thời báo Kinh tế Sài Gòn, "Doanh thu quảng cáo tại Việt Nam 2012 đạt 20.400 tỷ đồng, tăng 30\%" at ctdtst.vn/VNNDetails.aspx?l=vn/kinh-te/111757/quang-cao-viet-nam-2012-dat-20-400-tydong.html retrieved on Dec. 28, 2012

Veloutsou, C. \& L. Moutinho (2009), Brand Relationships Through Brand Reputation and Brand Tribalism", Journal of Business Research, 62, 314-322.

Woodside, A. G. \& M. G. Walser (2007), "Building Strong Brands in Retailing”, Journal of Business Research, 60(1), 1-10.

Yim, C.K., D. Tse \& K.D. Chan (2008), "Strengthening Customer Loyalty Through Intimacy and Passion: Roles of Customer-Firm Affection and Customer-Staff Relationships in Services", Journal of Marketing Research, 45(6), pp.741-56.

Yorkston, E. A., J. C. Nunes \& S. Matta (2010), “The Malleable Brand: The Role of Implicit Theories in Evaluating Brand Extensions”, Journal of Marketing, 74(January), 80-93. 